\title{
TRACE METAL CONCENTRATIONS IN Pleurozium schreberi AND Taraxacum officinale ALONG THE ROAD NO. 7
}

\author{
ZAWARTOŚCI METALI ŚLADOWYCH W Pleurozium schreberi \\ I Taraxacum officinale WZDŁUŻ DROGI NR 7
}

\begin{abstract}
The aim of this study is to test two plant species, the common dandelion Taraxacum officinale and moss Pleurozium schreberi, as bio monitors of trace metal pollution emitted by motor vehicles. The samples of the moss Pleurozium schreberi (green segments) and the common dandelion Taraxacum officinale (leaves) were collected within 12 transects along the state road No. E77 near Chyzne, Sothern Poland. The transects were located on the eastern and western side of the road (downwind and upwind towards prevailing winds), at the following distances from the road: 5, 50, 100, 300500 and $600 \mathrm{~m}$. Total concentrations of $\mathrm{Cr}, \mathrm{Cu}, \mathrm{Ni}, \mathrm{Pb}, \mathrm{Sb}$ and $\mathrm{Zn}$ in the plant material were determined. The studied species accumulated trace metals in the similar amounts. Statistically significant differences in metal concentrations between two plant species were observed only in the case of $\mathrm{Cu}$ and $\mathrm{Pb}$. Copper concentrations were higher in the common dandelion, while the moss Pleurozium schreberi accumulated considerably higher amounts of $\mathrm{Pb}$. There is a statistically significant negative correlation between the trace metal concentrations in plants and the distance to the road. There are also statistically significant differences in concentrations of $\mathrm{Cr}, \mathrm{Cu}, \mathrm{Ni}, \mathrm{Pb}$ and $\mathrm{Zn}$ in the common dandelion between the samples collected from the opposite sides of the road: upwind/downwind towards the prevailing wind direction at the distance up to 300 meters. The concentrations are higher on the downwind side of the road.
\end{abstract}

Keywords: biomonitoring, plants, Southern Poland, spatial distribution, trace metals, traffic pollution

\section{Introduction}

Road traffic is associated with emissions of many known hazardous and toxic substances. These include heavy or trace metals, polycyclic aromatic hydrocarbons (PAHs), volatile organic compounds (VOCs) and de-icing salts, among others [1, 2], which are emitted by motor vehicles and road infrastructure.

The following metals: $\mathrm{Ag}, \mathrm{Al}, \mathrm{As}, \mathrm{Ba}, \mathrm{Ca}, \mathrm{Cd}, \mathrm{Co}, \mathrm{Cr}, \mathrm{Cu}, \mathrm{Fe}, \mathrm{Hg}, \mathrm{Mn}, \mathrm{Mo}, \mathrm{Ni}, \mathrm{Pb}, \mathrm{Pd}$, $\mathrm{Pt}, \mathrm{Rh}, \mathrm{Sb}, \mathrm{Se}, \mathrm{Sr}, \mathrm{V}, \mathrm{Zn}$ are among the road traffic contaminants [3]. Among the most frequently studied heavy or trace metals, associated with road traffic pollution, are the most

\footnotetext{
${ }^{1}$ Department of Sustainability and Environmental Management, Faculty of Geography and Biology, Pedagogical University of Cracow, ul. Podchorążych 2, 30-084 Kraków

${ }^{2}$ AGH University of Science and Technology, Faculty of Mining Surveying and Environmental Engineering, Department of Environmental Management and Protection, al. A. Mickiewicza 30, 30-059 Kraków, email: epanek@agh.edu.pl

*Corresponding author: joanna.korzeniowska@up.krakow.pl
} 
toxic and emitted in the highest amounts: antimony, arsenic, barium, cadmium, chromium, cobalt, copper, iron, mercury, molybdenum, nickel, lead, platinum group elements (PGE: platinum, palladium, rhodium), vanadium and zinc.

Traffic-related metals introduced into the environment derive from many different sources of emissions, including vehicular: tires, brake and clutch linings, car bodies, motor parts, fuel additives, lubricants [4, 5] and non-vehicular sources: road pavement and embankment, roadside screens, de-icing substances [6-8]. Folkeson et al. [9] identify the following sources of road pollution: traffic and cargo, pavement and embankment materials, road equipment, maintenance and operation and external sources.

The main sources of $\mathrm{Ba}, \mathrm{Cd}, \mathrm{Cr}, \mathrm{Cu}, \mathrm{Mo}, \mathrm{Pb}, \mathrm{Sb}, \mathrm{Zn}$ are brake linings (pads) and tires $[1,4], \mathrm{Cd}, \mathrm{Cr}, \mathrm{Cu}, \mathrm{Hg}, \mathrm{Ni}, \mathrm{Pb}, \mathrm{V}$ and $\mathrm{Zn}$ derive from road pavement materials $[6,10], \mathrm{Ba}$, $\mathrm{Cd}, \mathrm{Cu}, \mathrm{Ni}, \mathrm{Zn}$ from lubricants [1], and $\mathrm{Cd}, \mathrm{Cr}, \mathrm{Cu}, \mathrm{Ni}, \mathrm{Pb}, \mathrm{Pt}, \mathrm{V}$ come from fossil fuel combustion, catalyst and antiknock additives [5]. The use of new technologies and materials has resulted in introducing new trace metal to the environment. For instance, banning leaded petrol (and introducing lead-free fuel) has resulted in a considerable decrease of $\mathrm{Pb}$ emissions. $\mathrm{Pb}$ is no longer an indicator of road pollution. However, such elements like $\mathrm{Ba}, \mathrm{Cr}, \mathrm{Cu}, \mathrm{Mo}, \mathrm{Sb}, \mathrm{Zn}$ and also platinum group elements (PGE) have been suggested as new tracers of traffic pollution [11].

Roadside pollution depends on many factors, i.e.: distance to the road, traffic density, road profile and also on environmental factors including: topography of adjacent area [3, 7, 12-14], land cover [8] and meteorological factors including precipitation, wind speed and wind direction $[12,13,15]$.

According to Piron-Frenet et al. [12] and Viard et al. [13], rainfall and wind patterns may, to some extent, influence the dispersion of particulate matter deposition and hence metal pollution. Road location with respect to the dominant wind directions determine propagation and dispersion of traffic emissions. The dominant wind direction may influence the extent to which the road affects the surrounding environment and may also cause disproportions in pollutant deposition on the both sides of the roads $[12,16]$.

In particular, dominant wind directions on the exposed road sections, crossing mountain ranges and open flat area, may influence irregularity in pollutant deposition on the both sides of the road. However, the wind direction in the mountain valleys follows the shape of the valley and hence the road direction [12].

Viard et al. [13], Masoudi et al. [15], Hagler et al. [16] and Bernhardt-Romermann et al. [17] report that road pollutants measured in road dust, soil and plants, at the same distance upwind and downwind of the road exhibit different concentration. The higher pollutant concentrations are usually observed at the downwind side of the road. The authors explain this pattern with the differences in dominant wind directions in the studied areas, which help remove pollutant particles from one side of the road to another.

Hagler et al. [16] find a nearly fivefold differences in ultrafine particle UFP concentrations between the upwind and downwind sites of the mayor road in North Carolina, USA. The highest UFP concentrations were observed in the nearest vicinity to the road on downwind direction. Studies conducted by Viard et al. [13] confirm the higher concentrations of $\mathrm{Pb}$ content in road dust measured on the downwind than the upwind side of the road. Deposition of deicing substances and nitrogen compound in soil, according to Bernhardt-Romermann et al. [17] affect motorways in Southern Germany up to $230 \mathrm{~m}$ on the downwind side of the road, in contrast to the upwind side, where it does not exceed $80 \mathrm{~m}$. Masoudi et al. [15] report distinctions in trace metals concentrations in soil samples 
collected at the same distance from the both sides of the road, explaining them by differences in wind directions and strength in the studied areas.

There is a very scarce literature, if any, concerning the influence of prevailing wind directions on the discrepancies in pollutant concentrations in plants on upwind versus downwind sites of the road, for instance: Graminaceae species [13] and mosses Pleurozium schreberi, Hylocomium splendens, Scleropodium purum and Abietinella abietyna [1].

Plant species are known as biological monitors and indicators of the environmental pollution. Their indication availabilities will reflect either the level of cumulated pollutants (bio monitors) or harmful effects imposed on organisms - bio indicators [18, 19]. Widely applied studies with use of bio monitors give the quantitative information on the quality of the environment, e.g., on atmospheric pollution. Most of research dealing with bio monitors provides information on trace element or heavy metal pollution [20-22]. Mosses are regarded to be very sensitive bio monitors of the pollution, because these species reflect atmospheric deposition of heavy metals and have been applied for several decades in environmental studies [1,23]. The level of heavy metals in mosses can be influenced by air pollution emission factors and modified by other factors such as: climate (precipitation), altitude, species, age and part of moss [18]. Moss species Pleurozium schreberi (Brid.) Mitt. along with Hylocomium splendens (Hedw.) B.S.G. are the most often used monitor species [24-26]. The species Pleurozium schreberi (Brid.) Mitt. is highly recommended because of its widespread occurrence as well as of its exceptional ability to accumulate elements from the air, reflecting environmental pollution. Well-developed surface of the plant helps to trap easily pollutant particles from the air, and the lack of cuticula layer enables it to retain and accumulate pollutants [18, 27]. The moss species including Pleurozium schreberi have been also used for monitoring of traffic related pollutants i.e., trace metals $[1,28]$.

In recent decades, vascular plants have been commonly applied as bio indicators and bio monitors because of their high abundance and widespread presence. Vascular plants monitor environmental changes in space and time [18]. However, most of the vascular species accumulate trace metals to the considerably lesser extent than mosses and lichens. For a long time, many authors have recommended the common dandelion Taraxacum officinale Weber as a suitable worldwide trace metal bio monitor and bio indicator reflecting quantitative air pollution [29-36]. The species is easy to identify, geographically widespread and occurs in meadows and pastures of various localities, including urban, industrial and agricultural areas, polluted to the various extent. The species reflects traffic-born pollution including trace metals [33-39].

The aim of this study is to test two plant species, the common dandelion Taraxacum officinale and moss Pleurozium schreberi, as bio monitors of spatial trace metals traffic pollution.

\section{Material and methods}

\section{Study area}

The study area was situated along the state road No. E77 (national road DK7) between villages Jablonka and Chyzne, county Nowy Targ in Sothern Poland, in the vicinity to the border crossing to Slovakia. Geographical coordinates: the latitude and longitude and elevation are $49^{\circ} 43^{\prime} \mathrm{N}, 19^{\circ} 67^{\prime} \mathrm{E}$ and $649 \mathrm{~m}$ above sea level respectively. According to Koppen classification, the area is characterized by temperate continental climate. The data 
for the average annual precipitation, temperature and wind speed are about $115 \mathrm{~mm}, 7.5^{\circ} \mathrm{C}$ and $10 \mathrm{~km} / \mathrm{h}$, respectively. The dominant wind directions are S, SSW and W for the analyzed area $[40,41]$.

The road no E77 plays an important role in the transit traffic towards southern Europe. The traffic density on the road section between Jablonka and the state border was about 5000 vehicles per day in 2015 and the speed limit was $90 \mathrm{~km}$ per hour [42].

\section{Sampling}

The samples were collected in 12 transects near the Slovak state border. The transects were located perpendicularly to the road, on the eastern and western side of the road, in the open area: meadows and pastures as well as in the woodland.

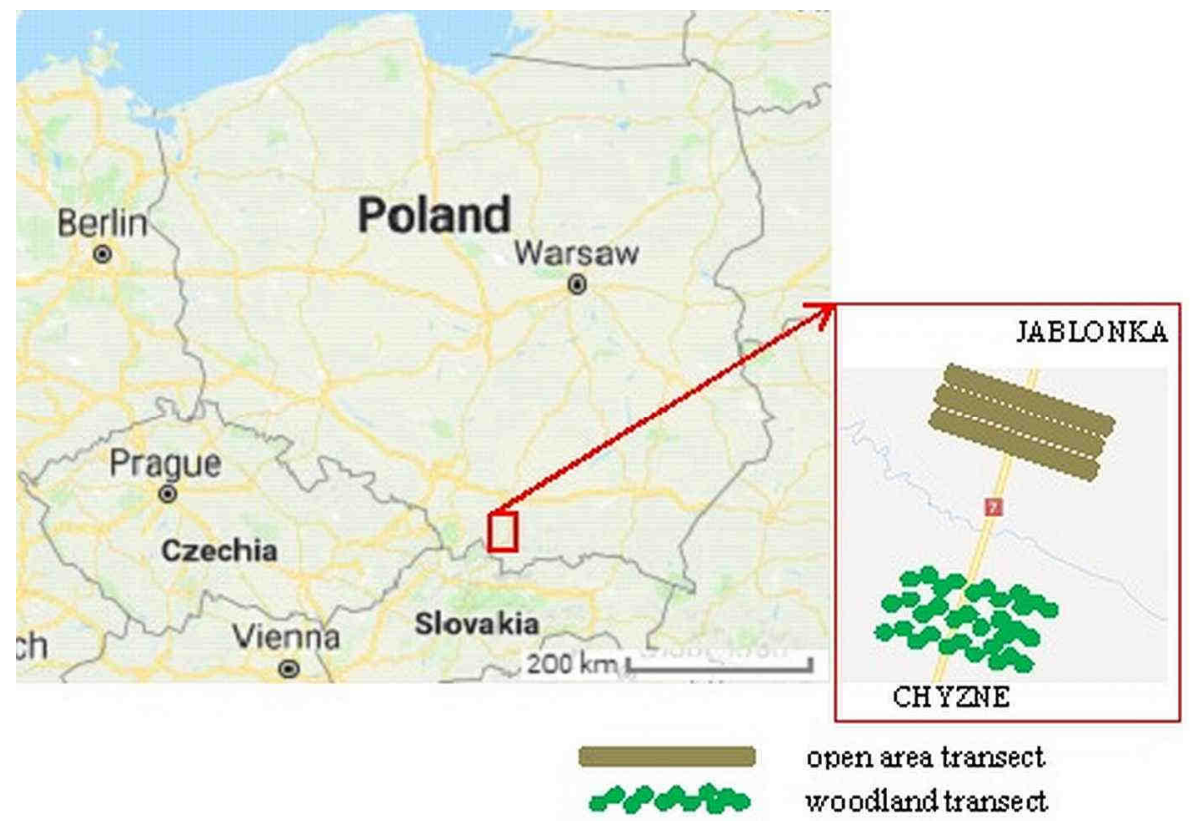

Fig. 1. Location of sampling sites

With respect to the prevailing wind direction, the transects were located upwind "non-road emission source" (E transects) and downwind "from road emission source" (W transects) relative to the road (Fig. 1). Each transect included six sampling sites at the following distances from the edge of the road: 5, 50, 100, 300, 500, $600 \mathrm{~m}$ (Fig. 2). In order to avoid the influence of local pollution sources sampling sites were situated at least $500 \mathrm{~m}$ from housing estates. The reference area was situated south of Chyzne village in the Jelesnia stream valley, at the minimal distance of about $5 \mathrm{~km}$ from roads and individual houses. 


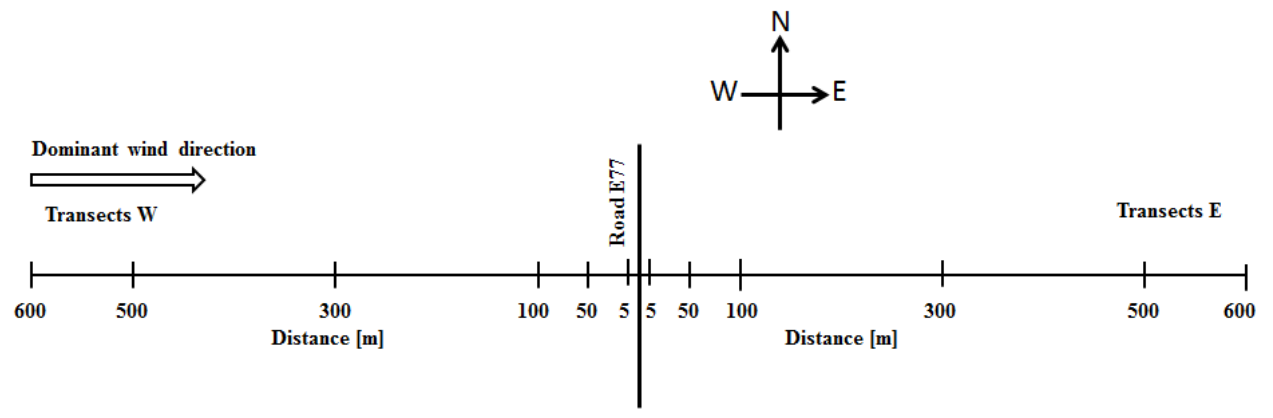

Fig. 2. Scheme of sampling transect

\section{Material}

Two biomonitor species, the moss species Pleurozium schreberi (Willd.) Mitten. and the common dandelion Taraxacum officinale Weber, were selected for the study. The selection criterion for species was their wide (common) distribution within sampling area.

Samples of the common dandelion were taken within six transects located in the open area and the moss samples within six transects in the woodlands (Fig. 1). Each species was sampled at 36 road sites. The mean sample of each species consisted of ten primary replicate samples collected in one site. In case of Taraxacum officinale the primary replicate sample consisted of 10-30 fully developed leaves, without imperfections, such as chlorosis or necrosis, taken from 3-5 individual plants. In case of carpet forming moss species Pleurozium schreberi, the primary replicate samples (green segments of shoots) were collected at least from 5 individual patches (clumps), not from under the tree crowns. In total 84 mean plant samples, including 12 reference samples, were taken. Field sampling was conducted after a few days without rainfall in September 2015. Material was placed in polyethylene bags.

\section{Methods}

\section{Chemical analysis}

According to suggestions of the following authors: Mankovska et al. [43] and Sawidis et al. [44] concerning sample preparation procedure, the plant material was left unwashed. The samples were dried in an electric drier at the temperature of $400{ }^{\circ} \mathrm{C}$ for $72 \mathrm{~h}$. Needles were separated from branches. Equal amounts of biomass from primary samples from the same plot were combined. Dry and homogenized samples were pulverized in an electric grinder. Portions of $0.4 \mathrm{~g}$ dry weight material were placed in teflon vessels. $5 \mathrm{~cm}^{3}$ of $65 \%$ $\mathrm{HNO}_{3}$ and $3 \mathrm{~cm}^{3}$ of $36 \% \mathrm{H}_{2} \mathrm{O}_{2}$ were added to each vessel. The mixture was mineralized in a microwave Berghof Speed Wave in temperature $200{ }^{\circ} \mathrm{C}$ and at pressure of $4 \mathrm{MPa}$. After processing the samples were diluted with deionized water to a total volume of $50 \mathrm{~cm}^{3}$ and filtered through hard paper filter. The final solutions were analysed for trace metals using flame atomic absorption spectrometry (FAAS) with a spectrophotometer model Hitachi Z 2000. Total concentrations of $\mathrm{Cr}, \mathrm{Cu}, \mathrm{Ni}, \mathrm{Pb}, \mathrm{Sb}$ and $\mathrm{Zn}$ were determined. 


\section{Statistical analysis of the data}

The statistical analysis was conducted using Statistica 10.0 software. The Shapiro-Wilk test was used to test whether the data followed the normal distribution. The Mann-Whitney $\mathrm{U}$ test was performed to examine whether differences in plant metal levels on upwind and downwind locations (sites) were statistically significant. The Mann-Whitney U test was also used to compare metal concentrations between the moss Pleurozium schreberi and the common dandelion Taraxacum officinale. The relationship between metal concentrations in plants and the distance from the road was tested by means of the Spearman $\mathrm{R}$ rank correlation coefficient $R$. The significance level $\alpha=0.05$ was established.

\section{Results}

\section{Plant species variations}

The mean concentrations of $\mathrm{Cr}, \mathrm{Cu}, \mathrm{Ni}, \mathrm{Pb}, \mathrm{Sb}$ and $\mathrm{Zn}$ in the moss species Pleurozium schreberi and the common dandelion Taraxacum officinale at the distances 5, 50, 100, 300, 500 and $600 \mathrm{~m}$ from the road are presented in Tables 1 and 2.

Table 1

Mean concentrations and standard deviations of trace metals in the moss species Pleurozium schreberi for $n=6$

\begin{tabular}{|c|c|c|c|c|c|c|c|}
\hline \multirow{2}{*}{$\begin{array}{l}\text { Side of } \\
\text { the road }\end{array}$} & \multirow{2}{*}{$\begin{array}{c}\text { Distance } \\
{[\mathbf{m}]}\end{array}$} & \multicolumn{6}{|c|}{ Trace metals [ $\mu \mathrm{g} / \mathrm{g}$ d.m.] } \\
\hline & & $\mathrm{Cr}$ & $\mathrm{Cu}$ & $\mathbf{N i}$ & $\mathbf{P b}$ & Sb & Zn \\
\hline \multirow{6}{*}{ W } & 5 & $84 \pm 15$ & $8.2 \pm 1.8$ & $39.0 \pm 8.1$ & $9.5 \pm 2.0$ & $0.68 \pm 0.28$ & $33.3 \pm 5.0$ \\
\hline & 50 & $75 \pm 12$ & $7.7 \pm 1.8$ & $37.4 \pm 8.5$ & $9.4 \pm 2.6$ & $0.67 \pm 0.24$ & $33.0 \pm 4.3$ \\
\hline & 100 & $72 \pm 12$ & $7.6 \pm 1.2$ & $37 \pm 10$ & $9.3 \pm 2.3$ & $0.67 \pm 0.21$ & $32.8 \pm 5.4$ \\
\hline & 300 & $53 \pm 16$ & $6.6 \pm 1.8$ & $33 \pm 13$ & $7.9 \pm 2.1$ & $0.57 \pm 0.26$ & $29 \pm 12$ \\
\hline & 500 & $36 \pm 12$ & $4.7 \pm 2.1$ & $26.4 \pm 8.2$ & $5.9 \pm 2.2$ & $0.45 \pm 0.16$ & $22.0 \pm 7.1$ \\
\hline & 600 & $35 \pm 10$ & $4.5 \pm 1.2$ & $26.0 \pm 6.4$ & $5.3 \pm 1.7$ & $0.28 \pm 0.13$ & $21.0 \pm 4.1$ \\
\hline \multirow{6}{*}{$\mathrm{E}$} & 5 & $76 \pm 30$ & $8.0 \pm 2.4$ & $38.5 \pm 8.5$ & $8.6 \pm 3.2$ & $0.82 \pm 0.28$ & $36 \pm 10$ \\
\hline & 50 & $71 \pm 22$ & $7.3 \pm 2.0$ & $35 \pm 11$ & $8.6 \pm 3.1$ & $0.78 \pm 0.36$ & $35.0 \pm 9.9$ \\
\hline & 100 & $63 \pm 25$ & $7.6 \pm 3.2$ & $38 \pm 12$ & $9.4 \pm 3.4$ & $0.73 \pm 0.32$ & $34.3 \pm 9.9$ \\
\hline & 300 & $64 \pm 19$ & $7.7 \pm 2.0$ & $35.9 \pm 9.7$ & $8.2 \pm 1.9$ & $0.68 \pm 0.26$ & $32 \pm 12$ \\
\hline & 500 & $44 \pm 10$ & $6.4 \pm 2.2$ & $33 \pm 12$ & $8.8 \pm 3.5$ & $0.5 \pm 0.2$ & $29.6 \pm 7.9$ \\
\hline & 600 & $46 \pm 11$ & $5.5 \pm 2.5$ & $30 \pm 13$ & $7.2 \pm 2.7$ & $0.39 \pm 0.17$ & $27.1 \pm 8.6$ \\
\hline \multicolumn{2}{|c|}{ Reference sites } & $35.0 \pm 4.4$ & $5.0 \pm 1.6$ & $25.8 \pm 6.3$ & $5.7 \pm 1.1$ & $0.29 \pm 0.16$ & $20.0 \pm 7.6$ \\
\hline
\end{tabular}

The metal concentrations in the moss species Pleurozium schreberi calculated for all sites $(5 \mathrm{E}, 50 \mathrm{E}, 100 \mathrm{E}, 300 \mathrm{E}, 500 \mathrm{E}, 600 \mathrm{E}, 5 \mathrm{~W}, 50 \mathrm{~W}, 100 \mathrm{~W}, 300 \mathrm{~W}, 500 \mathrm{~W}, 600 \mathrm{~W}$ and the reference sites) were as follows: $58 \pm 23 \mu \mathrm{g} \mathrm{Cr} / \mathrm{g}$ d.m.; $6.6 \pm 2.3 \mu \mathrm{g} \mathrm{Cu} / \mathrm{g}$ d.m.; $33 \pm 11 \mu \mathrm{g}$ Ni/g d.m.; $7.8 \pm 2.8 \mu \mathrm{g} \quad \mathrm{Pb} / \mathrm{g} \quad$ d.m.; $29.6 \pm 9.8 \mu \mathrm{g} \quad \mathrm{Zn} / \mathrm{g}$ d.m. and $0.56 \pm 0.29 \mu \mathrm{g} \mathrm{Sb} / \mathrm{g}$ d.m., and in the common dandelion Taraxacum officinale: $57 \pm 27 \mu \mathrm{g}$ Cr/g d.m.; $10.4 \pm 7.0 \mu \mathrm{g} \mathrm{Cu} / \mathrm{g}$ d.m.; $36 \pm 16 \mu \mathrm{g} \mathrm{Ni} / \mathrm{g} \mathrm{d} . \mathrm{m} . ; 6.8 \pm 4.0 \mu \mathrm{g} \mathrm{Pb} / \mathrm{g}$ d.m.; $45 \pm 38 \mu \mathrm{g} \mathrm{Zn} / \mathrm{g} \mathrm{d.m}$. and $0.63 \pm 0.46 \mu \mathrm{g} \mathrm{Sb/g} \mathrm{d.m.,} \mathrm{respectively.} \mathrm{Chromium} \mathrm{was}$ accumulated in the highest amounts in both plant species, while Sb was accumulated to a lesser extent. Descending sequences of average metal concentrations were as follows: for the moss Pleurozium schreberi: $\mathrm{Cr}>\mathrm{Ni}>\mathrm{Zn}>\mathrm{Pb}>\mathrm{Cu}>\mathrm{Sb}$ and for the common dandelion: $\mathrm{Cr}>\mathrm{Zn}>\mathrm{Ni}>\mathrm{Cu}>\mathrm{Pb}>\mathrm{Sb}$.

The examined plant species accumulated trace metals in similar amounts. The Mann-Whitney $U$ test showed statistically significant differences in metal concentrations between species only in the case of $\mathrm{Cu}$ and $\mathrm{Pb}$. Copper concentrations were 
higher in the common dandelion $(p<0.001)$, the moss Pleurozium schreberi accumulated considerably higher amounts of $\mathrm{Pb}(p<0.001)$, whereas the interspecies differences for other metal contents were not statistically significant.

Mean concentrations and standard deviations of trace metals

Table 2 in the common dandelion Taraxacum officinale for $n=6$

\begin{tabular}{|c|c|c|c|c|c|c|c|}
\hline \multirow{2}{*}{$\begin{array}{l}\text { Side of } \\
\text { the road }\end{array}$} & \multirow{2}{*}{$\begin{array}{c}\text { Distance } \\
{[\mathrm{m}]}\end{array}$} & \multicolumn{6}{|c|}{ Trace metals [ $\mu \mathrm{g} / \mathrm{g}$ d.m.] } \\
\hline & & $\mathrm{Cr}$ & $\mathrm{Cu}$ & $\mathrm{Ni}$ & $\mathbf{P b}$ & Sb & Zn \\
\hline \multirow{6}{*}{ W } & 5 & $89 \pm 14$ & $11.4 \pm 6.0$ & $48.6 \pm 6.9$ & $8.4 \pm 3.8$ & $1.40 \pm 0.67$ & $90 \pm 18$ \\
\hline & 50 & $56 \pm 14$ & $7.6 \pm 3.8$ & $38.1 \pm 7.3$ & $7.5 \pm 3.5$ & $0.72 \pm 0.26$ & $39.4 \pm 9.7$ \\
\hline & 100 & $47 \pm 20$ & $6.4 \pm 2.1$ & $31 \pm 14$ & $6.2 \pm 2.4$ & $0.84 \pm 0.63$ & $41 \pm 17$ \\
\hline & 300 & $42 \pm 11$ & $8.2 \pm 4.8$ & $26 \pm 12$ & $6.9 \pm 2.8$ & $0.59 \pm 0.27$ & $22.8 \pm 8.9$ \\
\hline & 500 & $38 \pm 12$ & $7.4 \pm 3.5$ & $25.5 \pm 5.8$ & $6.2 \pm 2.3$ & $0.38 \pm 0.19$ & $24.0 \pm 8.9$ \\
\hline & 600 & $35.7 \pm 8.6$ & $5.9 \pm 1.7$ & $26.6 \pm 6.9$ & $4.4 \pm 1.6$ & $0.34 \pm 0.15$ & $18.8 \pm 5.0$ \\
\hline \multirow{6}{*}{$\mathrm{E}$} & 5 & $109 \pm 32$ & $20.7 \pm 9.6$ & $75 \pm 14$ & $14.2 \pm 5.0$ & $0.95 \pm 0.48$ & $148 \pm 50$ \\
\hline & 50 & $76 \pm 25$ & $20.4 \pm 7.3$ & $43 \pm 13$ & $11.1 \pm 4.6$ & $0.80 \pm 0.36$ & $53 \pm 16$ \\
\hline & 100 & $71 \pm 23$ & $19.0 \pm 5.9$ & $36.7 \pm 9.4$ & $7.3 \pm 3.0$ & $0.74 \pm 0.34$ & $39 \pm 19$ \\
\hline & 300 & $59 \pm 12$ & $12.9 \pm 5.1$ & $33 \pm 14$ & $6.0 \pm 1.7$ & $0.62 \pm 0.35$ & $33 \pm 14$ \\
\hline & 500 & $44.8 \pm 7.8$ & $7.9 \pm 1.5$ & $30.2 \pm 7.7$ & $4.4 \pm 2.0$ & $0.55 \pm 0.30$ & $29.9 \pm 9.2$ \\
\hline & 600 & $38 \pm 13$ & $6.5 \pm 1.6$ & $29.7 \pm 7.9$ & $3.8 \pm 1.3$ & $0.48 \pm 0.26$ & $25.5 \pm 8.3$ \\
\hline \multicolumn{2}{|c|}{ Reference sites } & $35.9 \pm 7.8$ & $5.9 \pm 1.5$ & $24.9 \pm 6.8$ & $4.0 \pm 1.2$ & $0.18 \pm 0.08$ & $19.2 \pm 5.9$ \\
\hline
\end{tabular}

\section{Distance to the road}

There was a systematic relationship between metal concentrations in plants and the distance to the road. The moss and the common dandelion in the direct vicinity of the road $(5 \mathrm{~m})$ accumulated higher amounts of metals than those located at the distances of up to $600 \mathrm{~m}$. Enrichment coefficients calculated as a quotient of $\mathrm{Cr}, \mathrm{Cu}, \mathrm{Ni}, \mathrm{Pb}, \mathrm{Sb}$ and $\mathrm{Zn}$ concentrations in the moss and in the common dandelion at the distances of 5 and $600 \mathrm{~m}$ to the road were 2.0, 1.6, 1.4, 1.5, 2.2, 1.4 and 2.7, 2.6, 2.2, 2.8, 3.0, 5.3, respectively. Hence, one may conclude that the plants were influenced by vehicle emissions to the considerable extent. There was a negative and statistically significant correlation between metal concentrations in sampled plants and the distance to the road, regardless of whether the upwind or the downwind side of the road was considered and regardless of the plant species considered. In the case the moss Pleurozium schreberi, the most significant correlation was observed for chromium $(R=-0.82 ; p<0.001)$ and anthymone $(R=-0.61 ; p<0.001)$. The weakest correlations were found for lead and nickel. However, in the case of the common dandelion the most statistically significant correlations were found for chromium $(R=-0.78 ; p<0.001)$, lead $(R=-0.72 ; p<0.001)$, anthymone $(R=-0.72 ; p<0.001)$ and zinc $(R=-0.80 ; p<0.001)$, while the weakest correlations pertained to $\mathrm{Cu}$ contents of copper and nickel.

\section{Downwind versus upwind roadside variations}

The differences in metal concentrations between the downstream and the upstream group of roadside plants, regardless of the distance, were tested using the Mann-Whitney $U$ test. The $\mathrm{U}$ test did not show statistically significant differences between the wind direction (downwind "from road emission source" and upwind "non-road emission source") and metal concentrations in the moss Pleurozium schreberi, however, for the common dandelion statistically significant differences were observed in the case of $\mathrm{Cr}(p<0.05)$, 
$\mathrm{Cu}(p<0.001)$ and $\mathrm{Ni}(p<0.05)$. The concentrations of the above-mentioned metals were higher on the downwind side of the road.

There were statistically significant differences $(p<0.05)$ between metal concentrations in the dandelion samples collected up and downwind roadside, at the same distances. In particular, differences occurred in the case of $\mathrm{Cu}$ at distances of 5, 50, 100 and $300 \mathrm{~m}$, $\mathrm{Cr}$ for 50, 100, $300 \mathrm{~m}$ and in the case of $\mathrm{Ni}, \mathrm{Pb}$ and $\mathrm{Zn}$ only for $5 \mathrm{~m}$ from the road (Table 3). In the moss Pleurozium schreberi statistically significant differences $(p<0.05)$ were found only for chromium at the distance of $600 \mathrm{~m}(p=0.049)$.

Table 3

Differences in trace metal concentrations in the common dandelion Taraxacum officinale on the upwind and downwind roadside (Mann-Whitney Test U)

\begin{tabular}{|c|c|c|c|c|c|c|}
\hline \multirow{2}{*}{$\begin{array}{c}\text { Distance } \\
{[\mathbf{m}]}\end{array}$} & \multicolumn{7}{|c|}{ Metal } \\
\cline { 2 - 7 } & $\mathbf{C r}$ & $\mathbf{C u}$ & $\mathbf{N i}$ & $\mathbf{P b}$ & $\mathbf{S b}$ & $\mathbf{Z n}$ \\
\hline 5 & n.s. & $0.005741^{* *}$ & $0.000583^{* *}$ & $0.017216^{*}$ & n.s. & $0.005796^{* *}$ \\
\hline 50 & $0.041098^{*}$ & $0.000580^{* *}$ & n.s. & n.s. & n.s. & n.s. \\
\hline 100 & $0.034227^{*}$ & $0.000181^{* *}$ & n.s. & n.s. & n.s. & n.s. \\
\hline 300 & $0.004044^{* *}$ & $0.031146^{*}$ & n.s. & n.s. & n.s. & n.s. \\
\hline 500 & n.s. & n.s. & n.s. & n.s. & n.s. & n.s. \\
\hline 600 & n.s. & n.s. & n.s. & n.s. & n.s. & n.s. \\
\hline
\end{tabular}

${ }^{*} p<0.05,{ }^{* *} p<0.01$, n.s. - not statistically significant

\section{Discussion}

Kabata-Pendias and Pendias [45] have established the typical range of trace metal levels for mature leaf tissue in various species of vascular plants. These are as follows: $0.1-0.5 \mu \mathrm{g} \mathrm{Cr} / \mathrm{g}, 5$ to $30 \mu \mathrm{g} \mathrm{Cu} / \mathrm{g}, \quad 0.1-5.0 \mu \mathrm{g} \mathrm{Ni} / \mathrm{g}, 5-10 \mu \mathrm{g} \mathrm{Pb} / \mathrm{g}, 7-50 \mu \mathrm{g} \mathrm{Sb} / \mathrm{g}$, 27-150 $\mu \mathrm{g} \mathrm{Zn/g} \mathrm{d.m.} \mathrm{The} \mathrm{above-mentioned} \mathrm{authors} \mathrm{also} \mathrm{classified} \mathrm{the} \mathrm{following} \mathrm{ranges:}$ 5-30 $\mu \mathrm{g} \mathrm{Cr} / \mathrm{g}, 20-100 \mu \mathrm{g} \mathrm{Cu} / \mathrm{g}, 10-100 \mu \mathrm{g} \mathrm{Ni} / \mathrm{g}, 30-300 \mu \mathrm{g} \mathrm{Pb} / \mathrm{g}, 150 \mu \mathrm{g} \mathrm{Sb} / \mathrm{g}$ and $100-400 \mu \mathrm{g} \mathrm{Zn} / \mathrm{g}$ d.m. as toxic concentrations.

In our study, only $\mathrm{Cr}$ and $\mathrm{Ni}$ concentrations in green segments of the moss Pleurozium schreberi and in the leaves of common dandelion sampled at the distance of $5 \mathrm{~m}$ from the road exhibited toxic contents quoted by Kabata-Pendias and Pendias [45]. Chromium concentrations were almost three times higher than the toxic range. The data obtained for $\mathrm{Ni}$ were higher than the normal range and reached the toxic values. In addition, zinc contents were lower than toxic ranges and only slightly exceeded normal concentrations. Copper and lead contents did not reach toxic values for plants and fell within the normal range for plants. Antimony concentrations measured in this study were lower than normal ranges [45].

Generally, the level of element accumulation depends on the plant species. Nevertheless, the moss Pleurozium schreberi and the common dandelion did not differ widely in uptake efficiency. Regardless of the distance to the road, the common dandelion accumulated metals to a slightly higher extent than the moss species, with the exception of $\mathrm{Pb}$. This finding contradicts the earlier studies by Korzeniowska and Panek [46] carried along the forest area at the road Krakow-Zakopane, section Pcim-Zabornia, Southern Poland, which stated that the concentrations of $\mathrm{Cr}, \mathrm{Cu}, \mathrm{Ni}, \mathrm{Pb}$ and $\mathrm{Zn}$ in the moss Pleurozium schreberi were higher than those found in the common dandelion. The contents of $\mathrm{Cu}, \mathrm{Pb}$ and $\mathrm{Zn}$ in Pleurozium schreberi at Chyzne were 2-3 times lower than those 
observed along the road Krakow-Zakopane. It may be explained, to some extent, by the fact that traffic density on the road Krakow-Zakopane was twice as high as that of the road no E77 at Chyzne state. In the case of the common dandelion, metal concentrations at Chyzne were higher than those found along the road Krakow-Zakopane. The results obtained for the Pleurozium schreberi indicate that the roadside moss species accumulated several times higher amounts of metals than those observed in several moss species by Harmens et al. [47] in Europe, Krommer et al. [48] in Wienerwald Biosphere Reserve and Klos et al. [49] in forests of north-eastern Poland (especially for $\mathrm{Ni}$ and $\mathrm{Pb}$ ). There are available data on trace metal concentrations in the moss species Pleurozium schreberi along traffic routes are very scarce. Suoranta et al. [28] reported the following concentrations (mean value): $110 \mu \mathrm{g} \mathrm{Cr} / \mathrm{g}, 11 \mu \mathrm{g} \mathrm{Cu} / \mathrm{g}, 6.2 \mu \mathrm{g} \mathrm{Ni} / \mathrm{g}, 3.3 \mu \mathrm{g} \mathrm{Pb} / \mathrm{g}, 0.46 \mu \mathrm{g} \mathrm{Sb} / \mathrm{g}$ and $73 \mu \mathrm{g} \mathrm{Zn/g}$ for the highway in Oulu, Finland. Our present data for $\mathrm{Ni}, \mathrm{Pb}$ and $\mathrm{Sb}$ were several times higher when compared to those given by Suoranta et al. [28] for the Finnish roads.

The common dandelion Taraxacum officinale is regarded as a convenient environmental indicator. The mean metal concentrations in dandelion collected in Poland and reported by Kabata-Pendias and Pendias [45] are: $0.8 \mu \mathrm{g} \mathrm{Cr} / \mathrm{g}, 9.4 \mu \mathrm{g} \mathrm{Cu} / \mathrm{g}$, $3.4 \mu \mathrm{g} \mathrm{Ni} / \mathrm{g}, 1.1 \mu \mathrm{g} \mathrm{Pb} / \mathrm{g}$, and $45 \mu \mathrm{g} \mathrm{Zn/g}$. In contrast to the Pleurozium schreberi moss species, there are many studies referring to roadside metal pollution monitoring, using the Taraxacum officinale species (Czarnowska and Milewska [37] for Warszawa, Djingova et al. [33] for highways in Germany, Ligocki et al. [34] for Szczecin, Giacomino et al. [38] for Cuneo province, Italy and Kovacik et al. [36] for Kosice, Slovakia). Those results considerably exceeded mean values for Poland reported by Kabata-Pendias and Pendias [45] in the case of $\mathrm{Cr}, \mathrm{Ni}$ and $\mathrm{Pb}$, regardless of the distance from the road.

Proximity to the road is regarded to be the main factor affecting roadside environments. Road traffic results in higher pollutant concentrations in the environmental components in the direct proximity to the road. Metal concentrations in soils and plants decrease with distance from the road to reach background level at the distance ranging widely according to the various authors up to several hundred meters $[1,3,12,13]$.

In our study, metal concentrations in plant samples were significantly correlated with the distance to the road, regardless of the plant species considered. Our data showed considerably higher $\mathrm{Cr}, \mathrm{Ni}, \mathrm{Zn}$ concentrations in the direct proximity to the road, when comparing to the figures reported by Kovacik et al. [36] for the vicinity of traffic roads in Kosice and by Giacomino et al. [38] for Italian province of Cuneo. The data referring to the distance of 300-600 m matched the data reported by Kabata-Pendias and Dudka [29] for Poland, Czarnowska and Milewska [37] for Warszawa, Ligocki et al. [34] for Szczecin.

The existing literature finds differences between upwind and downwind concentrations of particle matter PM [16, 51, 52], metal contents in the roadside soils [13, 15] and in roadside plants [1, 13]. However, the results are mixed. Hagler et al. [16] find significant differences in ultrafine particle UFP concentrations between the upwind and downwind sites of the road with the higher amounts of UFP being observed downwind from the road. However, the results in Garcia et al. [51] concerning particle matter PM concentrations near highways show no evidence of a significant upwind source influence. Roorda-Knape et al. [50] and McGee et al. [52] report no correlation between PM concentrations and down/upwind road locations.

Viard et al. [13], Masoudi et al. [15] find $\mathrm{Cu}, \mathrm{Pb}, \mathrm{Zn}$ different concentrations in the soils at the upwind and downwind locations from the road at the same distance. The higher 
pollutant concentrations are usually observed at the downwind side of the road, towards the prevailing wind direction.

Among very few studies on influence of wind direction on metal concentrations in roadside plants, those performed by Zechmeister et al. [1] and Viard et al. [13] show differences of some trace metal contents in plants collected from two sides of the road. The authors conclude that higher values are found downwind from the road.

The prevailing wind direction, across our study area, is a southern one (1319 hours per year). Eastern winds are four times less frequent (190 hours per year than Western winds (759 hours per year)). The differences in prevalence of Western and Eastern winds may explain higher metal pollution on the downwind, eastern side of the southbound road.

Our study revealed statistically significant differences between metal concentrations in the common dandelion at the two sides of the road. The concentrations were higher on the west side (downwind from traffic emission sources). However, no differences in metal concentrations in the moss Pleurozium schreberi were observed. Plant cover influences, to some extent, pollutant dispersion in the vicinity to the road. The samples of the common dandelion were collected in the open area, whereas the moss Pleurozium schreberi in the forest. The forest trees may have played a role of natural screen, trapping dust particles, causing disturbances of wind stream, and thus hindering road pollutant propagation. This conclusion is in line with the work of Suchara et al. [26] who reported dependence of metal content in mosses on land cover: open area and woodland. Concentrations decreased with increasing tree density and canopy density.

Our results indicating statistically significant differences in metal contents in the common dandelion between upwind and downwind side of the road are similar to the conclusions of Viard et al. [13] for the Graminaceae and of Zechmeister et al. [1] for the mosses (though not for the moss Pleurozium schreberi).

\section{Conclusions}

1. The distance to the road influenced metal concentrations in both plant species. $\mathrm{Cr}, \mathrm{Cu}$, $\mathrm{Ni}, \mathrm{Pb}, \mathrm{Sb}$ and $\mathrm{Zn}$ concentrations decreased with the distance to the road.

2. Statistically significant differences in the metal content in the common dandelion between the upwind and the downwind sides of the road were observed. As expected, higher concentrations were found at the downwind locations.

3. The common dandelion accumulated trace metal in higher amounts than the moss species Pleurozium schreberi, however, the differences were not statistically significant. Nevertheless it can be regarded as a very suitable phytoindicator of metal traffic pollution in the open area, occurring widespreadly at the highly polluted sites, including direct vicinity to the road.

\section{Acknowledgement}

The study was performed in the Department of Environmental Management and Protection of the AGH Faculty of Mining Surveying and Environmental Engineering, Department of Environmental Management and Protection. It was financed by research project No. 11.11.150.008. 


\section{References}

[1] Zechmeister H, Hohenwallner D, Riss A, Hanus-Illnar A. Estimation of element deposition derived from road traffic sources by using mosses. Environ Pollut. 2005;138:238-49. DOI: 10.1016/j.envpol.2005.04.005.

[2] Wessolek G, Kluge B, Toland A, Nehls T, Klingelmann E, Rim YN, et al. Urban soils in the vadose zone. In: Endlicher W, editor. Perspectives in Urban Ecology. Berlin: Springer; 2011: 89-133. ISBN: 9783642177309. DOI: 10.1007/978-3-642-17731-6.

[3] Zechmeister H, Hagendorfer H, Hohenwallner D, Hanus-Illnar A, Riss A. Analyses of platinum group elements in mosses as indicators of road traffic emissions in Austria. Atmosph Environ. 2006;40:7720-32. DOI: 10.1016/j.atmosenv.2006.08.018.

[4] Harrison RM, Tilling R, Romero M, Harrad S, Jarvis K. A study of trace metals and polycyclic aromatic hydrocarbons in the roadside environment. Atmosph Environ. 2003;37:2391-402. DOI: 10.1016/S1352-2310(03)00122-5.

[5] Ozaki H, Watanabe I, Kuno K. As, Sb and $\mathrm{Hg}$ distribution and pollution sources in the roadside soil and dust around Kamikochi, Chubu Sangaku National Park, Japan. Geochem J. 2004;38:473-84. DOI: 10.2343/geochemj.38.473.

[6] Lindgren Á. Asphalt wear and pollution transport. Sci Total Environ. 1996;189-190:281-86. DOI: 10.1016/0048-9697(96)05220-5.

[7] Turer D. Effect of non-vehicular sources on heavy metal concentrations of roadside soils. Water Air Soil Pollut. 2005;166:251-64. DOI: 10.1007/s11270-005-7378-5.

[8] Zehetner F, Rosenfellner U, Mentler A, Gerzabek MH. Distribution of road salt residues, heavy metals and polycyclic aromatic hydrocarbons accross a highway-forest interface. Water Air Soil Pollut. 2009;198:125-32. DOI: 10.1007/s11270-008-9831-8.

[9] Folkeson L, Bękken T, Brenčič M, Dawson A, Frančois D, Kuřímská P, et al. Sources and fate of water contaminants in roads. Geotechnical, Geological and Earthquake Engineering. In: Dawson A, editor. Water in Road Structures. Dordrecht: Springer; 2009: 107-46. ISBN: 9781402085611. DOI: 10.1007/978-1-4020-8562-8_6.

[10] Kluge B, Wessolek G. Heavy metal pattern and solute concentrations in soils along the oldest highway of the world - the AVUS Autobahn. Environ Monit Assess. 2012;184:6469-81. DOI: 10.1007/s10661-011-2433-8.

[11] Hjortenkrans D, Bergbäck B, Häggerud A. New metal emission patterns in road traffic environments. Environ Monit Assess. 2006;117:85-98. DOI: 10.1007/s10661-006-7706-2.

[12] Piron-Frenet M, Bureau F, Pineau A. Lead accumulation in surface roadside soil. Its relationship to traffic density and meteorological parameters. Sci Total Environ. 1994;144:297-304. DOI: 10.1016/0048-9697(94)90449-9.

[13] Viard B, Pihan F, Promeyrat S, Pihan J-C. Integrated assessment of heavy metal ( Pb, Zn, Cd) highway pollution: bioaccumulation in soil, Graminaceae and land snails. Chemosphere. 2004;55:1349-59. DOI: 10.1016/j.chemosphere.2004.01.003.

[14] Saeedi M, Hosseinzadeh M, Jamshidi A, Pajooheshfar SP. Assessment of heavy metal concentration and leaching characteristics in highway side soils, Iran. Envion Monit Assess. 2009;151:231-41. DOI: 10.1007/s10661-008-0264-z.

[15] Masoudi SN, Ghajar Sepanlou M, Bahmanyar MA. Distribution of lead, cadmium, copper and zinc in roadside soil of Sari-Ghaemshahr road, Iran. Afr J Agric Res. 2012;7:198-204. DOI: 10.5897/AJAR11.1771.

[16] Hagler GS, Baldauf RW, Thoma ED, Long TR. Ultrafine particles near a major roadway in Raleigh, North Carolina: Downwind attenuation and correlation with traffic-related pollutants. Atmosph Environ. 2009;43:1229-34. DOI: 10.1016/j.atmosenv.2008.11.024.

[17] Bernhardt-Römermann M, Kirchner M, Kudernatsch T, Jakobi G, Fischer A. Changed vegetation composition in coniferous forests near to motorways in Southern Germany: the effects of traffic-born pollution. Environ Pollut. 2006;143:572-81. DOI: 10.1016/j.envpol.2005.10.046.

[18] Markert BA, Breure AM, Zechmeister HG. Bioindicators and Biomonitors. Principles, Concepts and Application. Amsterdam: Elsevier; 2003. ISBN: 9780080441771.

[19] Kłos A, Aleksiayenak YA, Ziembik Z, Rajfur M, Jerz D, Wacławek M, et al. The use of neutron activation analysis in the biomonitoring of trace element deposition in the Opole Province. Ecol Chem Eng S. 2013;20(4):677-87. DOI: 10.2478/eces-2013-0046.

[20] Zinicovscaia I, Aničić Urošević M, Vergel K, Vieru E, Frontasyeva MV, Povar I, et al. Active moss biomonitoring of trace elements air pollution in Chisinau, Republic of Moldova. Ecol Chem Eng S. 2018;25(3):361-72. DOI: 10.1515/eces-2018-0024.

[21] Qarri F, Lazo P, Allajbeu S, Bekteshi L, Kane S, Stafilov T. The evaluation of air quality in Albania by moss biomonitoring and metals atmospheric deposition. Arch Environ Contam Toxicol. 2019;76:554-71. DOI: 10.1007/s00244-019-00608-x. 
[22] Jóźwiak MA, Jóźwiak M. Bioindication as challenge in modern environmental protection. Ecol Chem Eng S. 2014;21(4):577-91. DOI: 10.1515/eces-2014-0041.

[23] Kłos A, Bochenek Z, Bjerke JW, Zagajewski B, Ziółkowski D, Ziembik Z, et al. The use of mosses in biomonitoring of selected areas in Poland and Spitsbergen in the years from 1975 to 2014. Ecol Chem Eng S. 2015;22(2):201-18. DOI: 10.1515/eces-2015-0011.

[24] Grodzińska K, Szarek-Łukaszewska G, Godzik B. Survey of heavy metal deposition in Poland using mosses as indicators. Sci Total Environ. 1999;229:41-51. DOI: 10.1016/S0048-9697(99)00071-6.

[25] Szarek-Łukaszewska G, Grodzińska S, Braniewski S. Heavy metal concentration in the moss Pleurozium schreberi in the Niepołomice forest, Poland: changes during 20 years. Environ Monit Assess. 2002;79:231-7. DOI: 10.1023/A:1020226526451.

[26] Suchara I, Sucharová J, Hola M, Reimann C, Boyd R, Filzmoser P, et al. The performance of moss, grass, and 1- and 2-year old spruce needles as bio indicators of contamination: A comparative study at the scale of the Czech Republic. Sci Total Environ. 2011;409:2281-97. DOI: 10.1016/j.scitotenv.2011.02.003.

[27] Kosior G, Samecka-Cymerman A, Kolon K, Kempers AJ. Bioindication capacity of metal pollution of native and transplanted Pleurozium schreberi under various levels of pollution. Chemosphere. 2010;81:321-6. DOI: 10.1016/j.chemosphere.2010.07.029.

[28] Suoranta T, Niemelä M, Poikolainen J, Piispanen J, Bokhari SNH, Meisel T, et al. Active biomonitoring of palladium, platinum, and rhodium emissions from road traffic using transplanted moss. Environ Sci Pollut Res. 2016;23:16790-801. DOI: 10.1007/s11356-016-6880-1.

[29] Kabata-Pendias A, Dudka S. Trace metal contents of Taraxacum officinale (dandelion) as a convenient environmental indicator. Environ Geochem Hlth. 1991;13(2):108-13. DOI: 10.1007/BF01734301.

[30] Djingova R, Kuleff I. Monitoring of heavy metal pollution by Taraxacum officinale. In: Markert B, editor. Plants as Biomonitors: Indicators for Heavy Metals in the Terrestrial Environment. New York: VCH; 1993: 435-60. ISBN: 1560812729. DOI: 10.1002/pca.2800060209.

[31] Królak E, Marciniuk J, Popijantus K, Wasilczuk P, Kasprzykowski Z. Environmental factors determining the accumulation of metals: $\mathrm{Cu}, \mathrm{Zn}, \mathrm{Mn}$ and $\mathrm{Fe}$ in tissues of Taraxacum sp. sect. Taraxacum. Bull Environ Contam Toxicol. 2018;101:68-74. DOI: 10.1007/s00128-018-2356-y.

[32] Gómez-Arroyo S, Barba-García A, Arenas-Huertero F, Cortés-Eslava J, de la Mora MG, García-Martínez R. Indicators of environmental contamination by heavy metals in leaves of Taraxacum officinale in two zones of the metropolitan area of Mexico City. Environ Sci Pollut Res Int. 2018;25:4739-49. DOI: 10.1007/s11356-017-0809-1.

[33] Djingova R, Kovacheva P, Wagner G, Markert B. Distribution of platinum group elements and other traffic related elements among different plants along some highways in Germany. Sci Total Environ. 2003;308:235-46. DOI: 10.1016/S0048-9697(02)00677-0.

[34] Ligocki M, Tarasewicz Z, Zygmunt A, Aniśko M. The common dandelion (Taraxacum officinale) as an indicator of anthropogenic toxic metal pollution of environment. Acta Sci Pol Zootechnica. 2011;10:73-82. http://agro.icm.edu.pl/agro/element/bwmeta1.element.agro-6d753b43-06ef-4336-8972-e327e99c11b9.

[35] Petrova S, Yurukova L, Velcheva I. Taraxacum officinale as a bio monitor of metals and toxic elements (Plovdiv, Bulgaria). Bulg J Agric Sci. 2013;19:241-7. https://www.agrojournal.org/19/02-10.pdf.

[36] Kováčik J, Dudáš M, Hedbavny J, Mártonfi P. Dandelion Taraxacum linearisquameum does not reflect soil metal content in urban localities. Environ Pollut. 2016;218:160-7. DOI: 10.1016/j.envpol.2016.08.030.

[37] Czarnowska K, Milewska A. The content of heavy metals in an indicator plant (Taraxacum officinale) in Warsaw. Pol J Environ Stud. 2000;9:125-8. http://www.pjoes.com/The-Content-of-Heavy-Metals-in-anIndicator-Plant-Taraxacum-Officinale-from-the-Warsaw,87286,0,2.html.

[38] Giacomino A, Malandrino M, Colombo ML, Miaglia S, Maimone P, Blancato S, et al. Metal content in dandelion (Taraxacum officinale) leaves: influence of vehicular traffic and safety upon consumption as food. J Chem. 2016;9. DOI: 10.1155/2016/9842987.

[39] Mleczek P, Borowiak K, Budka A, Niedzielski P. Relationship between concentration of rare earth elements in soil and their distribution in plants growing near a frequented road. Environ Sci Pollut Res Int. 2018;25:23695-711. DOI: 10.1007/s11356-018-2428-x.

[40] Beck H, Zimmermann N, McVicar T, Vergopolan N, Berg A, Wood E. Present and future Köppen-Geiger climate classification maps at 1-km resolution. Sci Data. 2018;5:180214. DOI: 10.1038/sdata.2018.214.

[41] Kundzewicz Z, Jania J. Extreme Meteorological and Hydrological Events in Poland. Geographia Polonica 2007;80. Warszawa: Institute of Geography and Spatial Organization, Polish Academy of Sciences; ISSN: 00167282. http://rcin.org.pl/igipz/Content/107/GP_80_2_cala.pdf.

[42] Dijkstra L, Poelman H, Ackermans L. Road Transport Performance in Europe. European Commission, Luxembourg: Publications Office of the European Union; 2019. ISBN: 9789276098072. DOI: $10.2776 / 046835$. 
[43] Maňkovska B, Godzik B, Badea O, Shiparyk Y, Moravcik P. Chemical and morphological characteristic of key tree species in the Carpathian Mountains. Environ Pollut. 2004;130:41-54. DOI: 10.1016/j.envpol.2003.10.020.

[44] Sawidis T, Breuste J, Mitrovic M, Pavlovic P, Tsigaridas K. Trees as bio indicator of heavy metal pollution in three European cities. Environ Pollut. 2011;159:3560-70. DOI: 10.1016/j.envpol.2011.08.008.

[45] Kabata-Pendias A, Pendias H. Trace Elements in Soils and Plants. Boca Raton London New York Washington, D.C: CRC Press; 2001. ISBN: 0849315751. http://base.dnsgb.com.ua/files/book/ Agriculture/Soil/Trace-Elements-in-Soils-and-Plants.pdf.

[46] Korzeniowska J, Panek E. The content of trace metals ( $\mathrm{Cd}, \mathrm{Cr}, \mathrm{Cu}, \mathrm{Ni}, \mathrm{Pb}, \mathrm{Zn}$ ) in selected plant species (moss Pleurozium schreberi, dandelion Taraxacum officianale, spruce Picea abies) along the road Cracow Zakopane. Geomatics Environ Eng. 2012;6(1):43-50. DOI: 10.7494/geom.2012.6.1.43.

[47] Harmens H, Norris DA, Sharps K, Mills G, Alber R, Aleksiayenak Y, et al. Heavy metal and nitrogen concentrations in mosses are declining across Europe whilst some "hotspots" remain in 2010. Environ Pollut. 2015;200:93-104. DOI: 10.1016/j.envpol.2015.01.036.

[48] Krommer V, Zechmeister H, Roder I, Scharf S, Hanus-Illnar A. Monitoring atmospheric ion in the biosphere reserve Wienerwald by a combined approach of biomonitoring methods and technical measurements. Chemosphere. 2007;67:1956-68. DOI: 10.1016/j.chemosphere.2006.11.060.

[49] Kłos A, Ziembik Z, Rajfur M, Dołhańczuk-Śródka A, Bochenek Z, Bjerke JW, et al. Using moss and lichens in biomonitoring of heavy-metal contamination of forest areas in southern and north-eastern Poland. Sci Total Environ. 2018;627:438-49. DOI: 10.1016/j.scitotenv.2018.01.211.

[50] Roorda-Knape MC, Janssen NAH, De Hartog JJ, Van Vliet PHN, Harssema H, Brunekreef B. Air pollution from traffic in city districts near major motorway. Atmosph Environ. 1998;32:1921-30. DOI: 10.1016/S1352-2310(97)00496-2.

[51] Garcia R, Hart JE, Davis ME, Reaser P, Natkin J, Laden F, et al. Effects of wind on background particle concentrations at truck freight terminals. J Occupational Environ Hygiene. 2007;4:36-48. DOI: $10.1080 / 15459620601070302$.

[52] McGee MA, Kamal AS, McGee JK, Wood CE, Dye JA, Krantz QT, et al. Differential effects of particulate matter upwind and downwind of an urban freeway in an allergic mouse model. Environ Sci Technol. 2015;49:3930-9. https://pubs.acs.org/doi/10.1021/es506048k. 